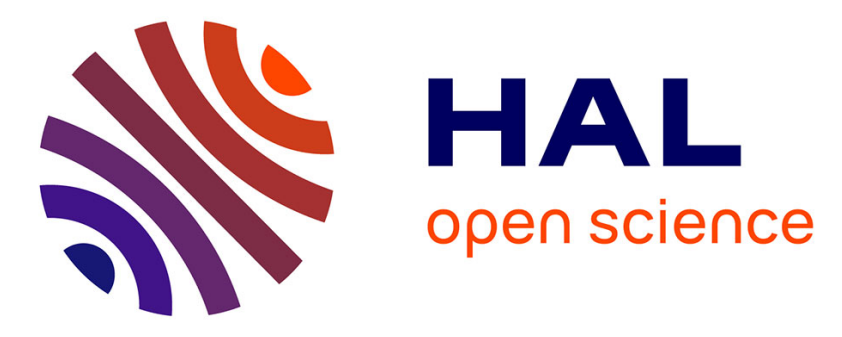

\title{
Insect Life Traits Are Key Factors in Mercury Accumulation and Transfer within the Terrestrial Food Web
}

Loïc Yung, Coralie Bertheau, David Cazaux, Nicole Regier, Vera Slaveykova, Michel Chalot

\section{To cite this version:}

Loïc Yung, Coralie Bertheau, David Cazaux, Nicole Regier, Vera Slaveykova, et al.. Insect Life Traits Are Key Factors in Mercury Accumulation and Transfer within the Terrestrial Food Web. Environmental Science and Technology, 2019, 53 (19), pp.11122-11132. 10.1021/acs.est.9b04102 . hal-02355645

\section{HAL Id: hal-02355645 \\ https://hal.science/hal-02355645}

Submitted on 4 Jan 2022

HAL is a multi-disciplinary open access archive for the deposit and dissemination of scientific research documents, whether they are published or not. The documents may come from teaching and research institutions in France or abroad, or from public or private research centers.
L'archive ouverte pluridisciplinaire HAL, est destinée au dépôt et à la diffusion de documents scientifiques de niveau recherche, publiés ou non, émanant des établissements d'enseignement et de recherche français ou étrangers, des laboratoires publics ou privés. 


\section{Insect life traits are key factors in mercury} Michel Chalot ${ }^{\Delta}$

6

7

${ }^{\Delta}$ UMR CNRS 6249 Chrono-environnement, Université Bourgogne Franche-Comté, F-25200 Montbéliard, France

Environmental and Aquatic Sciences, Earth and Environmental Sciences, Faculty of Sciences, 


\section{ABSTRACT}

As plants and associated insects are at the bottom of some terrestrial food webs, they are the primary contributors to mercury $(\mathrm{Hg})$ fluxes in ecosystems. In addition to the trophic position of these organisms, factors related to their life traits have been hypothesized to influence their exposure to $\mathrm{Hg}$. This study investigates the transfer of $\mathrm{Hg}$ in a soil-nettle-insect system and the insect-related factors affecting their $\mathrm{Hg}$ concentrations in a revegetated chlor-alkali landfill. Twenty-three insect species were identified and classified according to their life traits, their relationship with nettle and their morphological characteristics. We observed low total mercury $(\mathrm{THg})$ concentrations in nettles, with only $1 \%$ methylmercury $(\mathrm{MeHg})$ being detected, while concentrations ranged from 5 to $3700 \mu \mathrm{g} / \mathrm{kg}$ dry wt. in insects with a $\mathrm{MeHg}$ percentage of up to $75 \%$. The nettle-related insects were primarily exposed to $\mathrm{Hg}$ through the food web with significant biomagnification, particularly at the level of secondary predators. Within the nettle-unrelated group, the insect habitat was the most explanatory factor, with the highest enrichment being for the insects that spent part of their cycle in direct contact with $\mathrm{Hg}$ sources. Therefore, these insects require special attention because they are an essential vector of $\mathrm{Hg}$ transfer for terrestrial top predators.

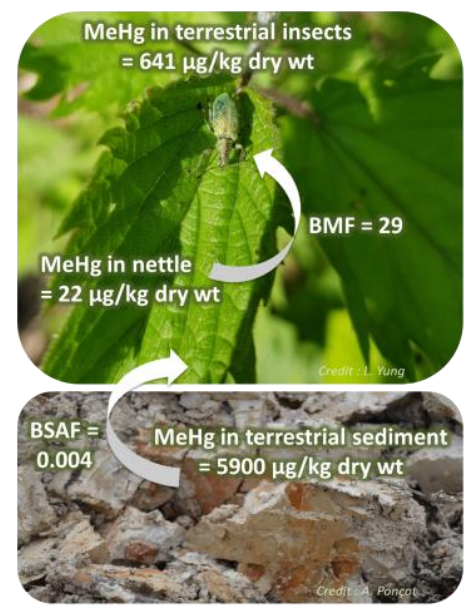




\section{INTRODUCTION}

Landfills in the chlor-alkali industries require stabilization of mercury $(\mathrm{Hg})$ to prevent air pollution by evaporated $\mathrm{Hg}^{1}$. Revegetation of these sites offers a suitable solution to confine the $\mathrm{Hg}$ released from the soil in plant biomass ${ }^{2}$, as plants are net sinks that incorporate the atmospheric $\mathrm{Hg}$ into leaf tissues ${ }^{3}$. These plantations, mainly from Salicaceous species (i.e., willow), favour the appearance of spontaneous herbaceous cover highly dominated by the common stinging nettle, Urtica diö̈ca L. (Urticaceae) ${ }^{4}$. In natural conditions, this nettle is considered an invertebrate "super-host" providing food for a large diversity of insects with different biology $y^{5}$ and is involved in strong trophic interactions ${ }^{6-8}$. In this context, herbivorous insects on revegetated landfills are potentially exposed to $\mathrm{Hg}$ and, more precisely, to methylmercury $(\mathrm{MeHg})$, the form of $\mathrm{Hg}$ that biomagnifies readily from soil and sediment to plants ${ }^{9}$. The accumulation of $\mathrm{MeHg}$ in herbivorous insects can cause serious physiological, neurological, behavioural and reproductive disorders for insects or invertebrate predators, birds and mammals through their diet ${ }^{10,11}$.

Studies and reviews focusing on $\mathrm{Hg}$ transfer in the terrestrial food chain and its toxicity on specific groups (i.e., birds, invertebrates, mammals, and microorganisms) have increased since $2010^{12,13}$. Some recent works, mainly targeting high trophic levels taxa, concluded that elevated $\mathrm{MeHg}$ concentrations in high trophic wildlife are ubiquitous across the world's ecosystems and that there is a lack of accurate information on the impact of $\mathrm{Hg}$ in terrestrial ecosystems ${ }^{14-17}$. Investigations in Chinese industrial areas showed that $\mathrm{Hg}$ level in the soil-plant-insect system increased from plants to herbivorous insects and to predators, showing a biomagnification primarily conditioned by trophic factors ${ }^{15,18-21}$.

Other factors such as the insect life stages can play a major role in the transfer of $\mathrm{Hg}$ through food webs and particularly from aquatic to terrestrial ecosystems ${ }^{22-24}$. Indeed, emerging aquatic insects such as chironomids ${ }^{25}$ or dragonflies ${ }^{26}$ that move to terrestrial biota 
can serve as both prey $^{27}$ and biovector of contaminants for local terrestrial consumers, including ants or spiders ${ }^{28,29}$. Consequently, the exposition of terrestrial insects is linked to the vicinity to aquatic biota and the Hg bioavailability, conditioned by the physical and chemical factors of these systems (e.g., dissolved organic carbon, quantity of aqueous nutrients $)^{25,30}$. For strictly terrestrial habitats, factors such as insect habitats, have been hypothesized to influence $\mathrm{Hg}$ accumulation in terrestrial insects ${ }^{18,31}$, but no studies examining biological and/or ecological factors affecting $\mathrm{Hg}$ concentrations in these organisms exist, as previously performed in lakes and wetlands ${ }^{25,32}$.

The present study aimed to study $\mathrm{Hg}$ uptake and biomagnification through an original and specific soil-plant-terrestrial insect system in a Hg-contaminated area in France and to estimate the extent to which insect-related factors affected $\mathrm{Hg}$ uptake. To that end, we used a chlor-alkali landfill revegetated by poplar plantations where the stinging nettle, Urtica dioïca L., colonized spontaneously the herbaceous layer, hosting a large diversity of insects. The specific objectives were i) to quantify $\mathrm{THg}$ (total $\mathrm{Hg}$ ) and $\mathrm{MeHg}$ in soil, different compartments of nettles and a large number of well-identified insect taxa; ii) to characterize insect taxa by their trophic guilds, feeding guilds, dietary range and habitats at both the larval and adult stages, their relationship with the nettle and their morphological characteristics (i.e., life stage and weight); and iii) to assess the relative importance of these factors on $\mathrm{THg}$ and $\mathrm{MeHg}$ concentrations in insects at the revegetated landfill.

\section{MATERIALS AND METHODS}

\section{Site description}

A phytomanagement field trial was implemented in 2011 on a chlor-alkali sediment landfill located in Saint-Symphorien-sur-Saône in the Bourgogne Franche-Comté region 
(France). The location, history and phytomanagement set-up at the sediment landfill have been described in detail in previous studies ${ }^{33,22}$. Five years after planting, biotic and abiotic environmental conditions have promoted the emergence of a spontaneous herbaceous cover strongly dominated by stinging nettle (Urtica diö̈ca L.). The control site is a natural area located at Courcelle-les-Montbéliard, $140 \mathrm{~km}$ east of the chlor-alkali plant, not directly influenced by the point-source.

\section{Sample collection}

To ensure the most representative diversity in insect species, the study was carried out over two consecutive years (2017 and 2018). Six poplar plots were selected at the experimental site, three with the Skado cultivar (Populus trichocarpa x P. maximowiczii) and three with the I-214 cultivar ( $P$. deltoides $\mathrm{x} P$. nigra). Soil and plant samples were collected in June 2017 and monthly in 2018 from April to September (i.e., during the vegetation period) for the experimental site and in July 2018 for the control site. Three samples of soil and nettle plants were composed of three mixed subsamples taken randomly within each sampling plot.

Soil samples consisting of bulk soil were collected from the first 20-cm layer, cleared from roots and other plant materials. Soil and plant samples were placed into plastic and paper bags, respectively, stored into a refrigerated container and shipped to the laboratory, where they were dried at ambient temperature $\left(24^{\circ} \mathrm{C}\right)$ for two weeks before $\mathrm{Hg}$ analyses. In parallel, an exhaustive sampling of the entomofauna related to the stinging nettle was carried out in the six studied plots monthly from April to September (i.e., period of insect activity) during the two consecutive years (2017 and 2018). At each plot (chlor-alkali and control sites), insects from six nettle patches of similar size were caught using a sweep net and pooled in a collector tube with absolute ethanol or ethyl-acetate as usually used to assure optimal preservation and identification. All samples were stored at $-20^{\circ} \mathrm{C}$ until identification and $\mathrm{Hg}$ analyses.

\section{Insect identification and characterization}


Among the whole insect diversity collected from the entomological survey, in the present study we targeted the most abundant taxa, representing $63 \%$ of the total insects collected on nettles at the experimental site during the two years. Prior to the analyses, each taxon was identified to the lowest possible taxonomic level using several references that included some identification keys ${ }^{35,36}$, on-line sources, such as insecte.org and/or specialists from the Franche-Comte Natural Spaces Conservatory. Each taxon was classified according to their life traits using published literature (SI Table S1). First, taxa were assigned according to their habitat both at the larval and adult stages, which allowed them to be split into two groups, "the nettle-related group", which included insects hosted by nettles (i.e., insects living on the nettle during their whole life cycle), and the "nettle-unrelated group", which refers to all other insects. We further classified taxa according to their trophic levels (i.e., herbivores, predators I or predators II), their larval and adult feeding guild (i.e., plant parts for herbivores and type of prey for predators) and their dietary range (i.e., insects that are host specific within a family were categorized as "specialists", and those that feed on plants or insects from more than one family were categorized as "generalists"). Finally, to test the influence of the morphological characteristics of insects on THg content, we identified the life stage of each taxon (larvae or adult) and measured the dry weight (mg).

\section{THg and MeHg analyses in soil, plants and insects}

Before analyses, dried nettle stems and leaves were separated and ground into a homogenous powder in a MM40 Mixer Mill (Retsch, Eragny sur Oise, France) for 4 min at 30 $\mathrm{Hz}$ and $7 \mathrm{~min}$ at $30 \mathrm{~Hz}$ for leaves and stems, respectively. Soil samples were manually homogenized and sieved to $<4 \mathrm{~mm}$. Insects euthanized with ethyl acetate were freeze-dried, and those euthanized with absolute ethanol were transferred into new plastic tubes and opened overnight at ambient temperature $\left(24^{\circ} \mathrm{C}\right)$ for the evaporation of ethanol. As the mass of some dried insects was $<1 \mathrm{mg}$, they were carefully weighed using a NewClassic MS analytical 
balance (Mettler-Toledo AG, Greifensee, Switzerland) with a five decimal resolution.

Preliminary tests showed no significant influence of the washing and preservation methods on THg concentrations measured in insects (SI, Figure S1). Moreover, in trophic interactions, the whole insects are usually ingested by predators, including the potential fraction of $\mathrm{Hg}$ adsorbed on the cuticle or internally accumulated through associated microorganisms (e.g., fungi and bacteria). Thus, whole insects were directly analysed without pretreatment to be closer to natural conditions. For the small insects, multiple individuals of the same taxa were pooled together to reach a minimal mass of $1 \mathrm{mg}$. $\mathrm{THg}$ concentrations were measured in the soil, plant and insect samples using an AMA-254 cold vapor atomic absorption (CV-AAS) Hg analyser (Altec Co., Czech Republic), as fully described in a previous study ${ }^{37}$. The instrument detection limit (DL) and the quantification limit (QL) using this method were 0.006 and 0.07 ng of $\mathrm{THg}$, respectively. For samples with non-detected $\mathrm{Hg}$, we calculated a $\mathrm{THg}$ concentration using the QL value.

To ensure that the preservation of different taxa in ethanol did not induce crosscontaminations, ethanol blank samples were regularly analysed. One hundred microliters of ethanol was placed into the sample container and evaporated. No $\mathrm{Hg}$ was detected in the ethanol fraction, which shows that $\mathrm{Hg}$ was not released into that fraction during storage.

$\mathrm{MeHg}$ was extracted from freeze-dried ground material using a $\mathrm{HNO}_{3}$ leaching / $\mathrm{CH}_{2} \mathrm{Cl}_{2}$ extraction method, as described by ${ }^{38}$. Briefly, 0.02 to $0.5 \mathrm{~g}$ of insect, nettle or soil material were weighed into a 50-mL centrifuge tube and homogenized into $2 \mathrm{~mL} 1 \mathrm{M} \mathrm{CuSO}_{4}$, $5 \mathrm{~mL} 5 \mathrm{M} \mathrm{HNO}_{3}$ and $10 \mathrm{~mL} \mathrm{CH}_{2} \mathrm{Cl}_{2}$, shaken for $1 \mathrm{~h}$ and centrifuged for $25 \mathrm{~min}$ at $3000 \mathrm{rpm}$. The solvent layer was transferred to a new tube and $\mathrm{MeHg}$ back-extracted into $10 \mathrm{~mL} \mathrm{H}_{2} \mathrm{O}$ (MilliQ) under $50 \mathrm{~mL} / \mathrm{min} \mathrm{N}_{2}$ flow in a water bath at $50^{\circ} \mathrm{C}$. $\mathrm{MeHg}$ was analysed as described elsewhere $^{39}$. The number of samples are provided in SI Table S2.

\section{Data analysis}



Team, 2013). All variables were checked for their homoscedasticity (Levene test) and normal distribution (Shapiro-Wilk test). Non-normal data were log transformed. Data that did not fit a normal distribution after transformation were analysed with nonparametric tests. All statistical tests were considered to be significant at $\mathrm{P}<0.05$. The results are presented as the means with their standard error (SE). Differences in THg concentrations in soil, nettles and insects between sites (experimental vs. controls) were assessed using the Mann-WhitneyWilcoxon test. In the experimental site, a comparison of $\mathrm{THg}$ and $\mathrm{MeHg}$ concentrations between soil, nettle, insect families and between nettle-related and nettle-unrelated insects was performed using a Kruskal-Wallis test and a Mann-Whitney-Wilcoxon test, respectively. A redundancy analysis (RDA) was performed on both the nettle-related and nettle-unrelated groups to assess the correlation between $\mathrm{THg}$ concentrations and the insect life traits studied using the "rda()" function available in the "vegan" package. The significance and rank of each

171 trait was then tested with the "envfits()" function (Monte Carlo test with 999 permutations). 172 Then, the effect of each significant insect life trait on $\mathrm{THg}$ concentrations for each group was 173 investigated with a Kruskal-Wallis test. For the morphological characteristics of insects, a 174 Mann-Whitney-Wilcoxon test was performed to assess whether THg concentrations differed 175 among insect stages. Pearson's or Spearman's correlation coefficients were calculated to 176 check for relationships between THg content and weight of insects grouped according to their 177 life traits.

178 The Biota-Soil Accumulation Factor (BSAF) was calculated for the nettles from the 179 experimental site and the control site according to the following equation:

$$
\text { BSAF nettle }=\frac{[\mathrm{THg}] \text { nettle }}{[\mathrm{THg}] \text { soil }}
$$


According to the information collected from the literature on trophic interactions (Table S1), we calculated the Bio-Magnification Factors (BMF) for nettle-related insects from the experimental site according to the following equation:

$$
\text { BMF taxa }=\frac{[\mathrm{THg}] \text { taxa }}{[\mathrm{THg}] \text { preys }}
$$

Trophic Magnification Factors (TMF) were determined for both $\mathrm{THg}$ and $\mathrm{MeHg}$ at the experimental site. TMF considered all taxa along the five level trophic web (i.e., plants, herbivorous insects, predator I, predator II, predator III) except those from the Elateridae species, which were removed from the herbivorous group as they accumulated large quantities of $\mathrm{Hg}$ through their life cycle. Hence, TMF were determined from the slope of a regression between the $\mathrm{Hg}$ concentrations and trophic level of insects in the food web and calculated as the antilog of the regression slopes (b):

$$
\log [\mathrm{Hg}]=\mathrm{a}+\mathrm{bTL}
$$

TMF refers to the average rate of change in contaminant concentrations from diet-to consumer along the trophic web. In TMF, slope values above zero are indicative of biomagnification (i.e., $\mathrm{TMF}>1)^{40}$.

\section{RESULTS}

\section{Characterisation of targeted taxa}

The present study covered insects from six orders: Coleoptera, Diptera, Hemiptera, Hymenoptera, Lepidoptera and Mecoptera, belonging to 16 common families within these orders (SI Table S1). The 23 targeted insect taxa were identified up to the family level for $100 \%$ of them, to the genus level for $96 \%$ and to the species level for $74 \%$. The identification of 16 caterpillars could not go beyond the order level. The 23 selected taxa were then 
classified according to their relationship or lack of relationship with nettle as a host-plant and their life traits (SI Table S1). The nettle-related group included 12 different genera of insects belonging to orders of Hemiptera and Coleoptera and unidentified families of Lepidopteran larvae (SI Table S1). These insects belonged to three different trophic guilds: herbivores, predators I and predators II. Herbivores belonged to taxa feeding on nettle sap, seeds or leaves during their larval or adult stages. Predators I were mainly specialists belonging to the family Coccinellidae and Miridae, which fed almost exclusively on aphids. Predators II were represented by the genus Nabis, which included certain species known as generalist predators that hunt herbivorous or other predatory species (i.e., aphids, Lepidopteran or Coleopteran larvae and some Heteropteran and Dipteran adults) on herbaceous layers. The nettle-unrelated group included all the other abundant taxa represented by 8 families (i.e., Formicidae, Panorpidae, Aphrophoridae, Chrysomelidae, Curculionidae, Elateridae, Chironomidae, and Sciomyzidae) and 9 genera. All taxa were sampled on nettles but were not directly related to it. Most of these taxa were characterized by a high mobility and a specific life cycle that occurred at different habitats, such as a larval cycle in the soil, in water or in snails as parasitoids.

\section{Hg concentrations in the soil-plant-insect system}

THg concentrations of soil, plant and insects were significantly higher at the experimental site than at the control site. The THg concentrations measured in soil samples from the experimental site were in the range of $4382-7119 \mu \mathrm{g} / \mathrm{kg}$ and 10 -fold higher than THg concentration $(570 \pm 70 \mu \mathrm{g} / \mathrm{kg})$ at the adjacent undisturbed forest soil ${ }^{33}$. Nettle stems and leaves were significantly more enriched in $\mathrm{THg}$ at the experimental site than their counterparts collected at the control site (Table 1). The BSAFs calculated for the experimental site and the control site were 0.004 and 0.011 , respectively, suggesting a noticeable dilution at 
both sites. With an average THg of $31 \pm 1 \mu \mathrm{g} / \mathrm{kg}$, leaves were significantly $(P<0.01)$ more enriched than stems $(11 \pm 1 \mu \mathrm{g} / \mathrm{kg} \mathrm{THg})$. A significant enrichment was observed in the nettle leaves during the season, with $\mathrm{THg}$ concentrations ranging from $18 \pm 5 \mu \mathrm{g} / \mathrm{kg}$ in samples collected in April to $31 \pm 5 \mu \mathrm{g} / \mathrm{kg}$ in samples collected in September $(P<0.01)$.

A total of 312 and 159 analyses of THg concentrations was performed on insects from the experimental and control sites, respectively (Table 1). Average THg concentrations for insects collected at the experimental site were significantly higher than those at the control site $(P<0.001)$, and this difference was found more specifically for 12 of the 14 compared families and orders (Table 1). Taxa (Cicadellidae family and Lepidoptera order), for which no significant differences were observed, had THg concentrations ranging from $<$ QL to 271 $\mu \mathrm{g} / \mathrm{kg}$ at the experimental site and from < QL to $109 \mu \mathrm{g} / \mathrm{kg}$ at the control site. No THg was detected in Nabidae from the control site, whereas elevated THg concentrations (ranging from 107 to $1805 \mu \mathrm{g} / \mathrm{kg}$ ) were measured for the same taxa collected at the experimental site, and the same phenomenon was observed for Aphididae and Aphrophoridae, although to a lesser extent. For most insects collected at the control site, THg concentrations remained $<53$ $\mu \mathrm{g} / \mathrm{kg}$, except for the highly mobile flying insects belonging to the Chironomidae and Panorpidae families, which presented the highest background concentrations (Table 1).

Table 1. Total mercury ( $\mathrm{THg}$ ) concentrations measured in nettles and the 16 families and order of insects from the sediment landfill and the control site. $\mathrm{n}$ represents the number of samples analysed. All concentrations are expressed in $\mu \mathrm{g} / \mathrm{kg}$ dry $w t \pm \mathrm{SE}$. 'NA' = taxa not collected at the control site. Concentrations measured in the sediment landfill were compared to those measured in the control site using the Wilcoxon rank sum test and the two-sample ttest. The results from the statistical comparisons are represented with the following legend: $P$ - 
251 forest $\operatorname{soil}^{21}$

\begin{tabular}{|c|c|c|c|c|c|c|}
\hline & \multirow{2}{*}{\multicolumn{2}{|c|}{$\begin{array}{c}\text { Experimental site } \\
\text { Experimental site } \\
\mathrm{THg}(\mu \mathrm{g} / \mathrm{kg})\end{array}$}} & \multirow{2}{*}{\multicolumn{2}{|c|}{$\begin{array}{c}\text { Control } \\
\text { Control sites } \\
\text { THg }(\mu \mathrm{g} / \mathrm{kg})\end{array}$}} & \multirow{4}{*}{$\begin{array}{c}\begin{array}{c}\text { Significance } \\
\text { test: }\end{array} \\
\text { comparison } \\
\text { of the means } \\
* * *^{\mathrm{a}}\end{array}$} \\
\hline & & & & & & \\
\hline \multicolumn{2}{|r|}{ Organism } & $\mathbf{n}$ & Mean \pm S.E & $\mathbf{n}$ & Mean \pm S.E & \\
\hline Soil & & 37 & $5894 \pm 111$ & $7^{a}$ & $570 \pm 70^{\mathrm{a}}$ & \\
\hline Nettles & & 187 & $21.4 \pm 1.0$ & 11 & $6.3 \pm 0.9$ & $* * *$ \\
\hline & Stems & 95 & $11.6 \pm 0.7$ & 5 & $3.8 \pm 1.1$ & $* * *$ \\
\hline & Leaves & 92 & $31.5 \pm 3.4$ & 6 & $8.4 \pm 0.7$ & $* * *$ \\
\hline Insects & Taxa & 312 & $388.5 \pm 38.5$ & 159 & $24.0 \pm 3.7$ & $* * *$ \\
\hline & Elateridae & 8 & $3679.8 \pm 372.7$ & 19 & $18.1 \pm 4.2$ & $* * *$ \\
\hline & Panorpidae & 6 & $1231.3 \pm 261.0$ & 3 & $178.6 \pm 96.2$ & $* *$ \\
\hline & Formicidae & 21 & $871.6 \pm 46.9$ & 16 & $11.8 \pm 3.4$ & $* * *$ \\
\hline & Nabidae & 67 & $617.3 \pm 47.2$ & 19 & $<D L$ & $* * *$ \\
\hline & Chironomidae & 32 & $518.1 \pm 29.3$ & 11 & $131.0 \pm 12.7$ & $* * *$ \\
\hline & Sciomyzidae & 5 & $200.8 \pm 38.9$ & NA & NA & NA \\
\hline & Chrysomelidae & 16 & $63.5 \pm 9.4$ & 12 & $18.0 \pm 4.7$ & $* * *$ \\
\hline & Coccinellidae & 13 & $59.8 \pm 20.4$ & 17 & $4.7 \pm 1.5$ & $* *$ \\
\hline & Curculionidae & 39 & $59.3 \pm 15.0$ & 15 & $6.1 \pm 2.9$ & $* * *$ \\
\hline & Cicadellidae & 21 & $53.2 \pm 9.6$ & 9 & $52.8 \pm 10.4$ & NS \\
\hline & Lepidoptera & 18 & $45.2 \pm 18.1$ & 8 & $38.7 \pm 10.5$ & NS \\
\hline & Rhyparochromidae & 17 & $19.3 \pm 4.1$ & NA & NA & NA \\
\hline & Aphididae & 22 & $10.1 \pm 1.2$ & 7 & $<\mathrm{DL}$ & $* * *$ \\
\hline & Miridae & 17 & $8.9 \pm 2.4$ & 13 & $4.2 \pm 3.3$ & $*$ \\
\hline & Pentatomidae & 3 & $7.1 \pm 2.7$ & 6 & $0.5 \pm 0.3$ & $*$ \\
\hline & Aphrophoridae & 7 & $5.7 \pm 1.8$ & 4 & $<\mathrm{DL}$ & $* *$ \\
\hline
\end{tabular}

The 16 studied families from the experimental site were plotted according to their $\mathrm{THg}$ concentration (Figure 1). 


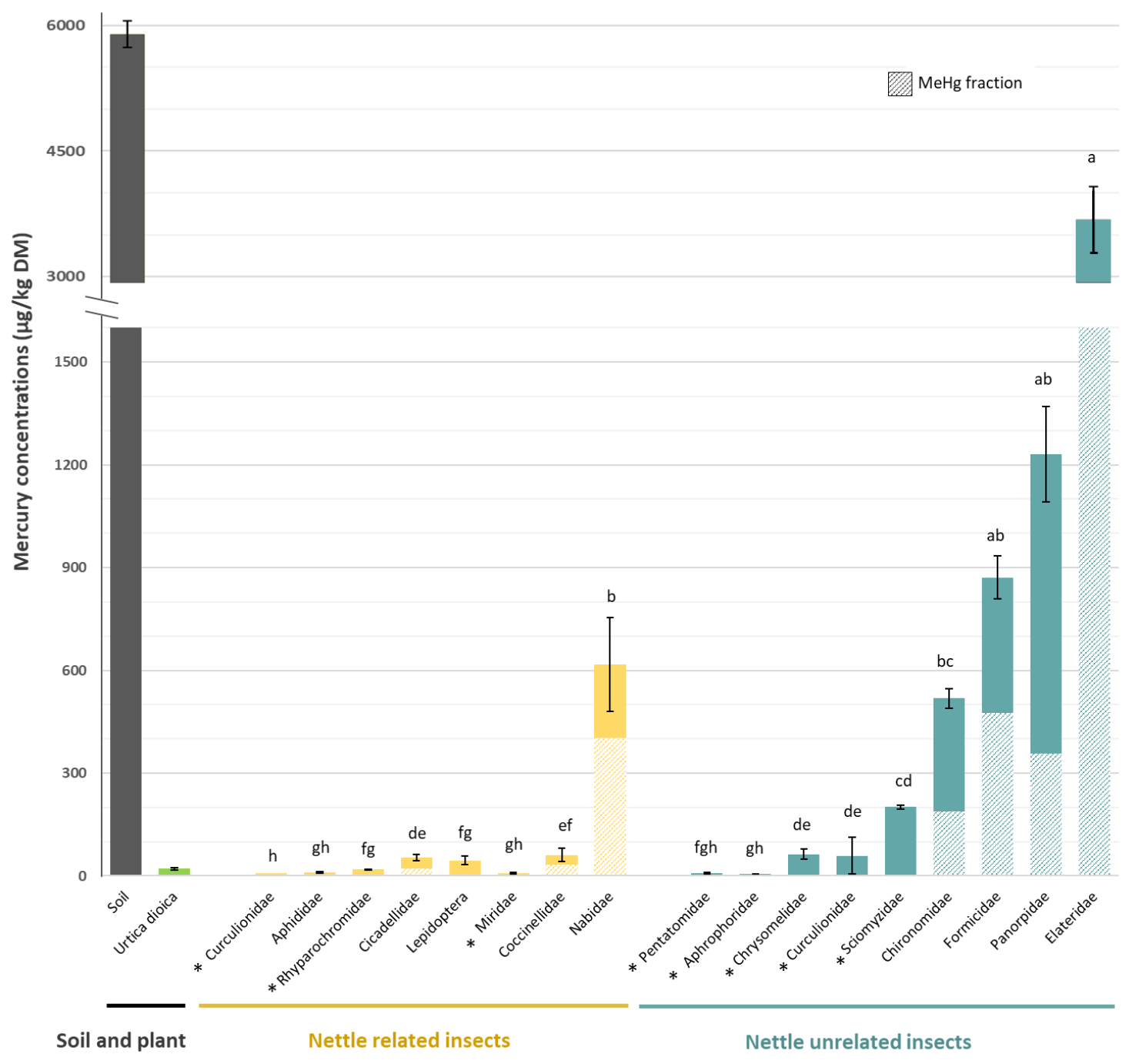

260 Figure 1. Mean THg concentrations (full bar, $\mu \mathrm{g} / \mathrm{kg}$ dry wt.), including the MeHg fraction (hatched bar, \%), plotted for soil and nettles (Urtica diö̈ca) and for all the investigated insect taxa from the nettle-unrelated and nettle-related groups. $*=$ The MeHg concentrations were not analysed. Bars with the same letter did not differ significantly from each other using a pairwise Kruskal-Wallis test $(P<0.05)$.

The highest $\mathrm{THg}$ concentrations were measured in Elateridae, Panorpidae and Formicidae followed by Chironimidae and Nabidae, with concentrations higher than 500 $\mu \mathrm{g} / \mathrm{kg}$ dry wt., which are significantly different from Elateridae $(3679.8 \pm 372.7 \mu \mathrm{g} / \mathrm{kg})$. The measured THg concentrations dropped to $200 \mu \mathrm{g} / \mathrm{kg}$ for Sciomizidae and below $100 \mu \mathrm{g} / \mathrm{kg}$ for each other family. Within the Curculionidae family, THg concentrations were variable, 
ranging from $<\mathrm{QL}$ to $321 \mu \mathrm{g} / \mathrm{kg}$, with concentrations over $150 \mu \mathrm{g} / \mathrm{kg}$ for Phyllobius $s p$. and up to $56 \mu \mathrm{g} / \mathrm{kg}$ for the two other considered species (SI Table S1). All other less enriched families had THg concentrations in the same order of magnitude as those measured for nettles. Overall, nettle-unrelated insects showed mean THg concentrations $(981 \pm 96 \mu \mathrm{g} / \mathrm{kg})$ six times higher than nettle-related insects $(124 \pm 14 \mu \mathrm{g} / \mathrm{kg})$ (Figure 1). Within the nettlerelated group, mean THg concentrations ranged from $8.9 \pm 2.4$ for Miridae to $617.3 \pm 47.2$ $\mu \mathrm{g} / \mathrm{kg}$ for Nabidae. Concerning the nettle-unrelated group, the lowest mean $\mathrm{THg}$ concentrations were obtained for Aphrophoridae and Pentatomidae, whereas the highest concentrations were found in Elateridae. However, the THg enrichment seems not to be only related to the relationship with nettle. Indeed, the nettle-related taxon Nabidae had $\mathrm{THg}$ concentrations not significantly different from the nettle-unrelated taxa Panorpidae, Formicidae and Chironimidae (Figure 1).

Additionally, no significant difference $(P>0.05)$ was found between the lowest mean THg concentrations in the nettle-unrelated group and those in the nettle-related group. Despite high $\mathrm{THg}$ concentrations, the percentage of $\mathrm{MeHg}$ in the soil was very low $(0.03 \pm 0.002 \%)$, slightly increased in nettles $(1.2 \pm 0.1 \%)$ and considerably increased in insects (ranging from $5.6 \%$ to $74.2 \%$ ). Insect $\mathrm{MeHg}$ (average $29.2 \%$, a) being significantly different $(P<0.05)$ from nettle $\mathrm{MeHg}(8.0 \%, \mathrm{~b})$, and soil $\mathrm{MeHg}$ (average $4.5 \%$, b).

The percentages of MeHg were not significantly different between the nettle-related group and the nettle-unrelated group $(P>0.05)$ with mean values of $43 \pm 7 \%$ and $49 \pm 5 \%$, respectively. Within the nettle-related group, for the 5 studied families, the percentage of MeHg was higher than $25 \%$ and reached $65 \%$ for Nabidae, except for Lepidoptera, for which $\mathrm{MeHg}$ only represented 6\% of THg. Elateridae from the nettle-unrelated group exhibited $74 \%$ $\mathrm{MeHg}$, representing over $2700 \mu \mathrm{g} / \mathrm{kg}$. The Panorpidae family presented the most variable MeHg percentages, ranging from 4 to $70 \%$. 
The present study clearly demonstrated that insect life traits, such as habitat, trophic guild, feeding guild, and dietary range, at both the larval and adult stages significantly influenced the mean $\mathrm{THg}$ concentrations of insects living at the landfill $(P<0.01)$. However, the relative importance of each of these life traits on $\mathrm{THg}$ concentrations of insects in the two groups (nettle-related vs. nettle-unrelated insects) was different (Table 2).

Table 2. Hierarchical analysis of factors affecting THg concentrations within the nettleunrelated and nettle-related groups. $P$-value ${ }^{\prime * * * '} 0.001^{\prime * * \prime} 0.01^{\prime * 1} 0.05$ 'NS' not significant.

\begin{tabular}{|l|l|c|c|c|}
\hline \multicolumn{2}{|l|}{ Factors } & r2 & $\operatorname{Pr}(>\mathbf{r})$ & Significativity \\
\hline \multicolumn{2}{|l|}{ Nettle-related group } & & & \\
\hline & Trophic guild & 0.39 & 0.001 & $* * *$ \\
\hline & Feeding guild (adult) & 0.39 & 0.001 & $* * *$ \\
\hline & Feeding guild (larvae) & 0.39 & 0.001 & $* * *$ \\
\hline & Dietary range & 0.37 & 0.001 & $* * *$ \\
\hline & Habitat (larvae) & 0.07 & 0.017 & $*$ \\
\hline & Habitat (adult) & 0 & 1 & NS \\
\hline & Nettle-unrelated group & & & $* * *$ \\
\hline & Habitat (adult) & 0.22 & 0.001 & $* * *$ \\
\hline & Feeding guild (larvae) & 0.21 & 0.001 & $* *$ \\
\hline & Habitat (larvae) & 0.16 & 0.002 & NS \\
\hline & Feeding guild (adult) & 0.06 & 0.115 & $*$ \\
\hline & Dietary range & 0.05 & 0.037 & NS \\
\hline & Trophic guild & 0.02 & 0.475 & \\
\hline
\end{tabular}

According to the RDA, THg concentrations in nettle-unrelated insects were mainly influenced by the adult habitat $(P<0.001)$, then by the dietary range at larval stage $(P<$ $0.001)$ and by larval habitat $(P<0.002)$, while the trophic guild and adult feeding guild factors were not critical. Considering adult habitat, $\mathrm{THg}$ concentrations followed the 
following order: insects living on host plants < insects having their larval cycle in underwater sediments $<$ insects living a part of their life cycle in terrestrial sediments (Figure 2A).

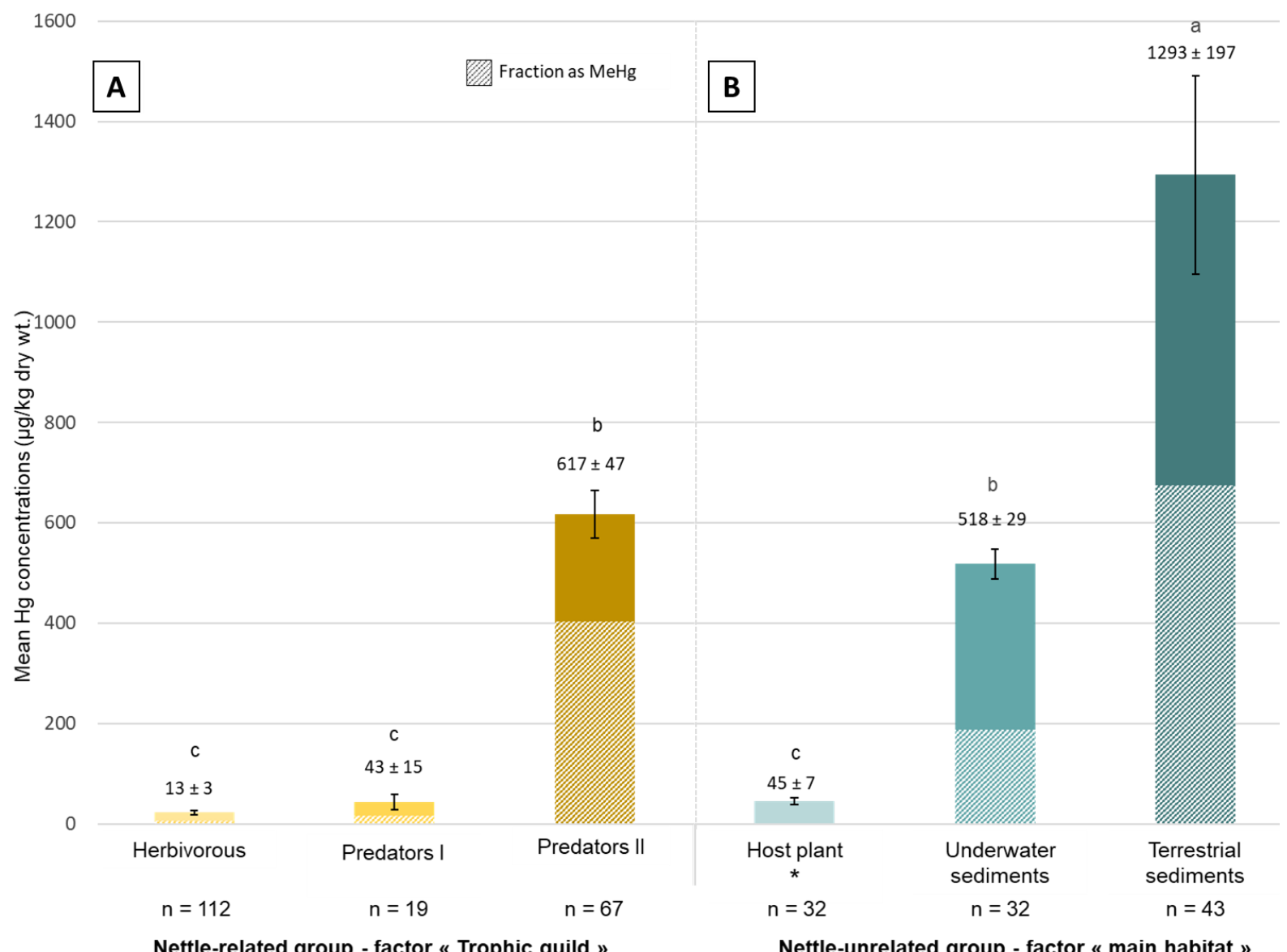

312 Figure 2. Mean THg concentrations (full bars, $\mu \mathrm{g} / \mathrm{kg}$ dry wt.) $\pm \mathrm{SE}$ and the $\mathrm{MeHg}$ fraction 313 (hatched bars, \%), measured in classes related to the main factors influencing the $\mathrm{Hg}$ enrichment for both the nettle-related group (factor = trophic guild, A) and external group (factor = main habitat, B). *: The MeHg concentrations were not analysed. Bars with the same letter did not differ significantly from each other using a pairwise Kruskal-Wallis test $(P<$ $0.05)$.

The THg concentrations in Aphrophora alni (Aphrophoridae), which perform their complete life cycle on plants (especially Salicaceous species), did not exceed $12 \mu \mathrm{g} / \mathrm{kg}$ dry wt. In contrast, taxa with part of their life cycle in soil, such as Agriotes sp., Phyllobius sp., 
had average $\mathrm{THg}$ contents higher than $200 \mu \mathrm{g} / \mathrm{kg}$ with a mean percentage of $\mathrm{MeHg}$ over $50 \%$. Insects belonging to the genus Crepidodera, which also feed on Salicaceae, had the lowest THg content for insects with a part of their life cycle in the soil but still significantly higher than those measured for Aphrophora alni $(P<0.01)$ (Figure 1).

For nettle-related insects, feeding guild at larval and adult stages $(P<0.001)$, trophic guild $(P<0.001)$ and then dietary range $(P<0.001)$, accounting individually for more than $37 \%$ of the total variability, were the most significant life traits (Table 2). Thus, in the nettlerelated food web, the THg contents were in the following order: herbivores $<$ soft-body insect predators $<$ generalist insect predators (Figure 2B), with a percentage of MeHg following the same trend: $24 \%<37 \%<65 \%$. Herbivorous insects presented no significant $\mathrm{THg}$ enrichment compared with nettles, but the mean $\mathrm{MeHg}$ concentrations increased from $0.3 \mu \mathrm{g} / \mathrm{kg}$ in nettles to $9.1 \mu \mathrm{g} / \mathrm{kg}$ in herbivorous insects. The biomagnification within the nettle-related group was also observed while considering all the studied taxa (including those from the nettle-unrelated group), with TMF of 2.8 for $\mathrm{THg}$ and 6.3 for $\mathrm{MeHg}$.

Each family of insects feeding on nettle sap or nettle seeds had a BMF lower than 1.0, except for leafhoppers (Cicadellidae), which had the highest BMF (4.6) among all herbivorous insects. THg concentrations ( $\mu \mathrm{g} / \mathrm{kg}$ ) for herbivorous insects increased as follows: seed-feeder $(13 \pm 3 \mu \mathrm{g} / \mathrm{kg})<$ sap-sucking $(22 \pm 5 \mu \mathrm{g} / \mathrm{kg})<$ leaf-feeder $(37 \pm 10 \mu \mathrm{g} / \mathrm{kg})$ with no significant differences between these feeding guilds. With regard to defoliating insects, Lepidoptera larvae, which included unidentified taxa with potential generalist feeding specificity, had a BMF of 1.4, whereas that of a specialist species of weevils (Curculionidae) hosted by nettles was 0.6 . No significant THg enrichment was obtained for predators I, which included ladybirds (Coccinellidae) and a predatory bug (Miridae), compared to herbivorous insects. Damsel bugs (Nabidae), which were the only studied generalist predators II of the 
nettle-related food web, had average concentrations 15 times (THg) and more than 30 times

$347(\mathrm{MeHg})$ higher than those measured in the lower trophic guild, resulting in a BMF of 4.8.

The influence of the development stage on THg concentrations was studied on two 349 predatory taxa: the ladybirds, Harmonia axiridis (Coccinellidae) and the damsel bugs, Nabis sp. (Nabidae). THg concentrations measured in the imago ladybirds $(\mathrm{n}=6)$ were 10 -fold higher $(P<0.001)$ than those measured in larvae $(\mathrm{n}=7)$. In contrast, no significant difference was obtained for Nabidae species between the imago (from 148 to $1786 \mu \mathrm{g} / \mathrm{kg} ; \mathrm{n}=43$ ) and the larvae (from 108 to $1805 \mu \mathrm{g} / \mathrm{kg} ; \mathrm{n}=24$ ). A significant positive correlation between the weight of insects and their THg content was observed when all taxa were pooled $\left(r_{\mathrm{s}}=0.62, P\right.$ $<0.001)$. The THg content in insects increased proportionally with their weight but differently according to the group studied. We also considered the main life traits, that is, the 357 habitat of nettle-unrelated taxa and the trophic guild for nettle-related taxa. In doing so, the correlation between THg and weight was confirmed for herbivores $\left(r_{\mathrm{s}}=0.60, P<0.001\right)$ and predators $\left(r_{\mathrm{s}}=0.62, P<0.001\right)$ trophic guilds as well as for underwater sediments $\left(r_{\mathrm{s}}=0.44\right.$, $P<0.01)$ and terrestrial sediments $\left(r_{\mathrm{s}}=0.81, P<0.001\right)$ habitats (Figure 3 ). 


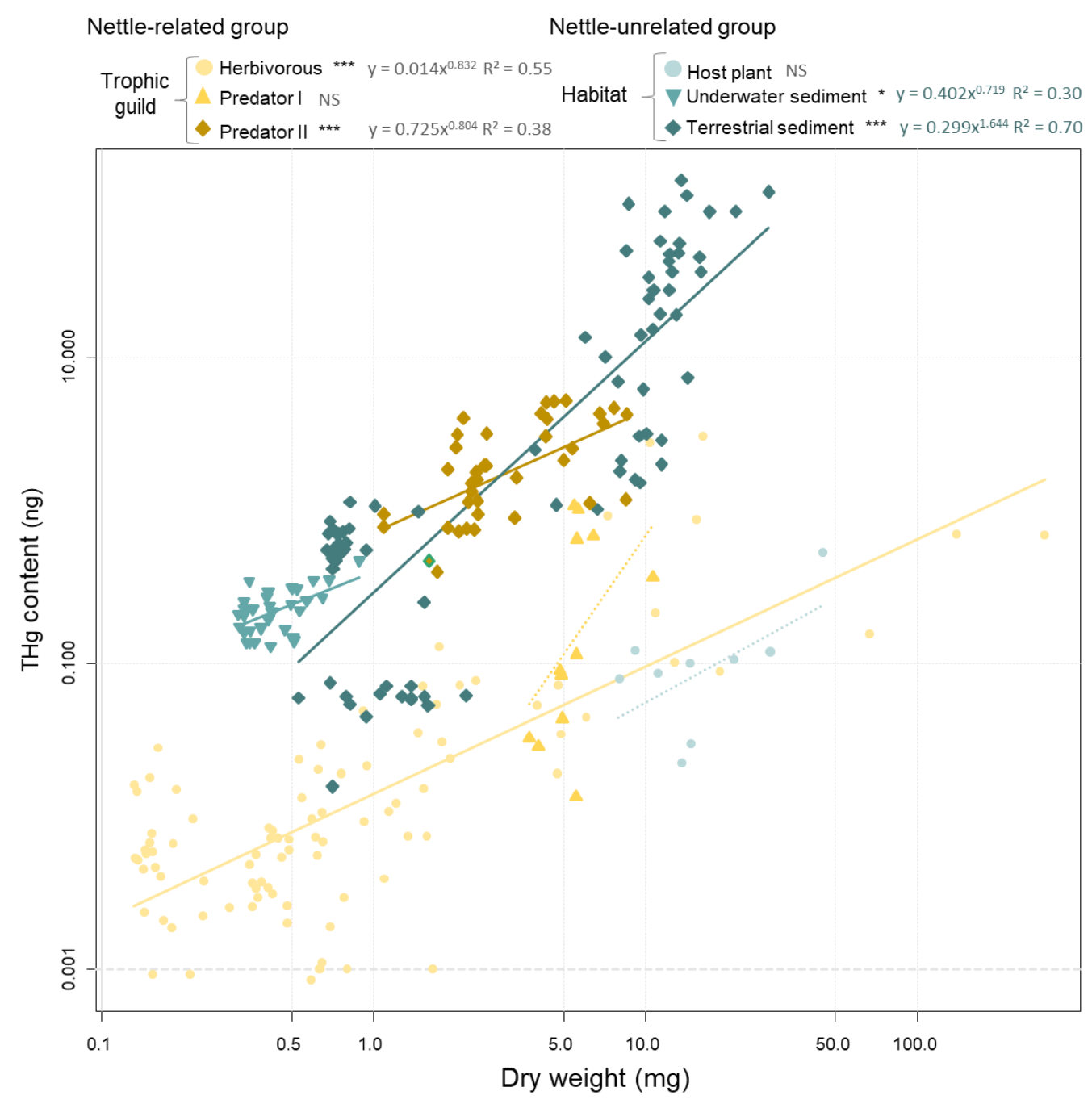

363 Figure 3. Relationships between the dry weight (mg) and the $\mathrm{THg}$ content (ng) of insects measured in 6 classes, 3 related to the "trophic guild" or 3 related to the "habitat" factors. The results from Pearson's and Spearman's correlation tests are presented with the following legend: $P$-value ${ }^{\prime * * * 1} 0.001^{\prime * * 1} 0.01^{\prime * 1} 0.05$ 'NS' not significant. The regression equations were calculated, as well as the regression coefficient $\left(R^{2}\right)$ for each class, for which a correlation was obtained.

The first cluster, characterized by a high equation coefficient $(\mathrm{a}>0.3)$, comprised most taxa from the nettle-unrelated insects that spent part of their life cycle in direct contact 371 with $\mathrm{Hg}$ sources, i.e. Elateridae, Curculionidae, Chironomidae, Formicidae and Panorpidae species. This cluster also included nettle-related predators II (i.e., Nabidae species), predators 
I (Coccinellidae) and herbivores (Lepidoptera), which accumulated only $\mathrm{Hg}$ via biomagnification from the diet. The second cluster, characterized by a lower coefficient in the equation (calculated when significant, a $<0.1$ ), mainly included nettle-related herbivorous insects and predators $\mathrm{I}$, as well as insects strictly living on Salicaceous species (i.e., Cerpopidae, Pentatomidae). This cluster also included a specific beetle (i.e., Chrysomelidae), which spent a short period of its life cycle in terrestrial sediments.

\section{DISCUSSION}

Our data provided evidence on the terrestrial biomagnification of $\mathrm{Hg}$ at the soil-plantinsect food web at a chlor-alkali site. These results reinforce recently published work in which Hg biomagnification not only concerns wetlands but also a wider range of biota, including terrestrial biota $^{41}$. As a result of the chlor-alkali process, $\mathrm{Hg}$ enrichment at the sediment landfill were similar to those measured at a mining area in Turkey $^{42}$ and the Liaoning Province in China ${ }^{19,21}$ but 10 -fold lower than the Wanshan Mercury Mining District in China $^{14}$. Mean THg concentration from our soil samples $(5.9 \mathrm{mg} / \mathrm{kg})$ was also 20 -fold higher than the average value for global agrosystem soils $(0.3 \mathrm{mg} / \mathrm{kg})^{43}$ and 60 -fold higher than the mean concentration in natural surface soil $(0.1 \mathrm{mg} / \mathrm{kg})^{44}$. Overall, soils in the vicinities of chlor-alkali plants have $\mathrm{Hg}$ concentrations ranging from 0.06 to $100 \mathrm{mg} / \mathrm{kg}^{45}$. The methylated form of $\mathrm{Hg}$ only represented $0.03 \%$ of the $\mathrm{THg}$, which is very low compared to the common rate of $1 \%$ to $3 \%$ for terrestrial sediments ${ }^{44}$. However, similar rates of $\mathrm{MeHg}$ in the previously mentioned Wanshan District (from 0.02 to $0.11 \%$ ) to the rates of our samples were observed $^{46}$.

Low $\mathrm{Hg}$ concentrations were measured for the various tissues of nettles spontaneously growing under the studied poplar plantation, with average THg concentrations not exceeding $100 \mathrm{ng} / \mathrm{kg}$ for stems and leaves. These concentrations were in the same order of magnitude 
than those measured for the Skado poplar cultivar (i.e., $42.5 \mu \mathrm{g} / \mathrm{kg}$ dry wt.) ${ }^{34}$. The obtained 399 concentrations in nettles were lower than the average $\mathrm{THg}$ concentration $(206 \mu \mathrm{g} / \mathrm{kg})$ measured in the shoots of 12 native herbaceous plant species collected in the previously mentioned mining area in Turkey ${ }^{42} . \mathrm{Hg}$ concentrations in mature leaf tissues above $1-8 \mathrm{mg} / \mathrm{kg}$ have been reported to be excessive or toxic to plants ${ }^{45}$ with a potential $10 \%$ yield loss in agronomic species ${ }^{47}$. These thresholds reported in the literature are 10 to 80 times higher than those measured in nettle leaves in our study. A recent study conducted on the same site concluded that $\mathrm{Hg}$ entry into poplar leaves was exclusively through an atmospheric pathway ${ }^{2}$. If this property also applies to nettle, it may explain the higher $\mathrm{Hg}$ concentrations measured in the nettle leaves compared to the stems.

Insects from the revegetated sediment landfill had $\mathrm{Hg}$ concentrations ranging from background values to $5500 \mu \mathrm{g} / \mathrm{kg}$, which is consistent with studies conducted in industrialized areas with comparable $\mathrm{Hg}$ concentrations in terrestrial sediments. Lepidopteran larvae, Formicidae, and Chrysomelidae, had THg concentrations comparable to those measured in previous studies ${ }^{18,19}$. Given the TMF for $\mathrm{THg}$ (2.8) and $\mathrm{MeHg}$ (6.3) within the 5 trophic levels, our data suggest that $\mathrm{Hg}$ biomagnified at the soil-nettle-insect food web (Figure 4). Our results are in agreement with studies that considered a wider range of taxonomic groups, including insects, birds and mammals ${ }^{14-17}$. Our study did not include the latter two higher trophic levels but rather focused on a much higher number of insect taxa and a more accurate level of trophic interactions.

The present study covers a wide taxonomic range of insects for which the accuracy of identification enabled the characterization of several life traits. This functional diversity provided us with a decent overview of the functioning ecosystem and enabled us to study these life traits as factors influencing $\mathrm{Hg}$ enrichment in insects. Thus, taxa from the experimental site were enriched in $\mathrm{Hg}$ to varying degrees, depending on several factors, 
including the trophic level, linked to the feeding guild and the feeding specificity. However, the fact that within the nettle-unrelated group, an herbivorous species (Elateridae) had $\mathrm{THg}$ concentrations exceeding those of secondary predators, such as ants or Panorpidae, led us to consider other factors, including those conditioning a direct contact with contaminant sources.

Among all of the taxa considered, Elateridae were the most enriched in both $\mathrm{Hg}$ and $\mathrm{MeHg}$, with concentrations in the same order of magnitude as those measured in soil. As herbivorous taxa feeding mainly on the poplar cultivars with a comparable enrichment than nettles ${ }^{34}$, Elateridae should not have been exposed to high amounts of $\mathrm{Hg}$ from their diet. These elevated concentrations may be related to direct cuticle contact with the dredged sediments during the larval cycle. As already mentioned for $\operatorname{ants}^{18}, \mathrm{Hg}$ in soil can indeed penetrate their cuticle by uptake or passive diffusion when prolonged dermal contact has occurred. Elateridae larvae, also known as wireworms, have spent most of their life in the soil, including 3-4 months for eggs, 2-5 years as larvae, and can overwinter as adults ${ }^{48}$. The other taxa investigated that may be exposed to $\mathrm{Hg}$ through prolonged dermal contact during their larval cycle are Panorpidae that have spent $1-2$ years in the soil ${ }^{49}$ and Chironomidae spending one to several years in underwater sediments ${ }^{50}$. The landfill we investigated in the present study was indeed constructed in the vicinity of a mitigation pond ${ }^{37}$. The lower $\mathrm{THg}$ concentrations measured in adult Chironomidae compared to Elateridae may be related to a greater loss of $\mathrm{Hg}$ during metamorphosis, as proven for some metals, including $\mathrm{Hg}^{51}$, or to an active detoxification mechanism ${ }^{52}$. Although the $\mathrm{THg}$ concentrations in the soil and in Elateridae were in the same order of magnitude, the concentration of $\mathrm{MeHg}$ was approximately 2000-fold higher in Elateridae, suggesting the entry of the methylated form of $\mathrm{Hg}$ or the potential methylation of inorganic $\mathrm{Hg}$ once taken up. The diet of wireworms mainly consists in decomposed plant matter, and its associated fungal and microbial biomass, which are known to be involved in the methylation of $\mathrm{Hg}$ in forest floor ${ }^{53}$. A recent study already 
hypothesized that decomposition of the soil organic matter pool introduces additional $\mathrm{MeHg}$

449 to the diets of detritivore invertebrates ${ }^{54}$. Consequently, the high concentration of $\mathrm{Hg}$

450

451

452

453 measured in Elateriade seemed to be related to both their feeding guild and habitat during their larval stage. Further studies on insect traits related to their development intrinsic, such as the duration of the larval cycle, duration and location during overwinter or diapause, are needed to improve our knowledge regarding $\mathrm{Hg}$ accumulation in insects.

Within the nettle-related food web, the $\mathrm{THg}$ concentrations increased as follows: nettles $<$ herbivores $<$ predator specialists $<$ predator generalists, with a gap between predator specialists (including Coccinellidae) and predator generalists, suggesting a likely entry of $\mathrm{Hg}$ from another source at this level. Nabidae, which were the only predator generalist in the nettle-related insects, only hunt on the herbaceous layer ${ }^{55}$ with rare contact with the soil surface. Adult Chironomidae, which most likely grew as larvae in the adjacent contaminated pond $^{37}$ where they became contaminated by $\mathrm{Hg}$, were abundant on nettles. In this context, Chironomidae were potential prey for Nabidae and, consequently, biovectors from aquatic to terrestrial environments. A previous study showed that Chironomidae, among emerging insects, were the main contributors to the transfer of biomass and polyunsaturated fatty acids from aquatic to terrestrial ecosystems, representing a superior food quality for terrestrial consumers $^{22}$. With comparable $\mathrm{THg}$ concentrations (Figure 1) and similar relationships between $\mathrm{THg}$ and biomasses (Figure 3), Chironomidae probably played the role of the biovector of $\mathrm{Hg}$ from aquatic sediments to Nabidae (Figure 4). Thus, we demonstrated that the feeding specificity of insects might also be considered an explanatory factor, as generalist insects are exposed to high amounts of $\mathrm{Hg}$ while feeding on emerging insects. These results were consistent with those for predatory spiders ${ }^{24,29,56}$, which are also generalist species and fed on Hg-enriched Chironomidae. 


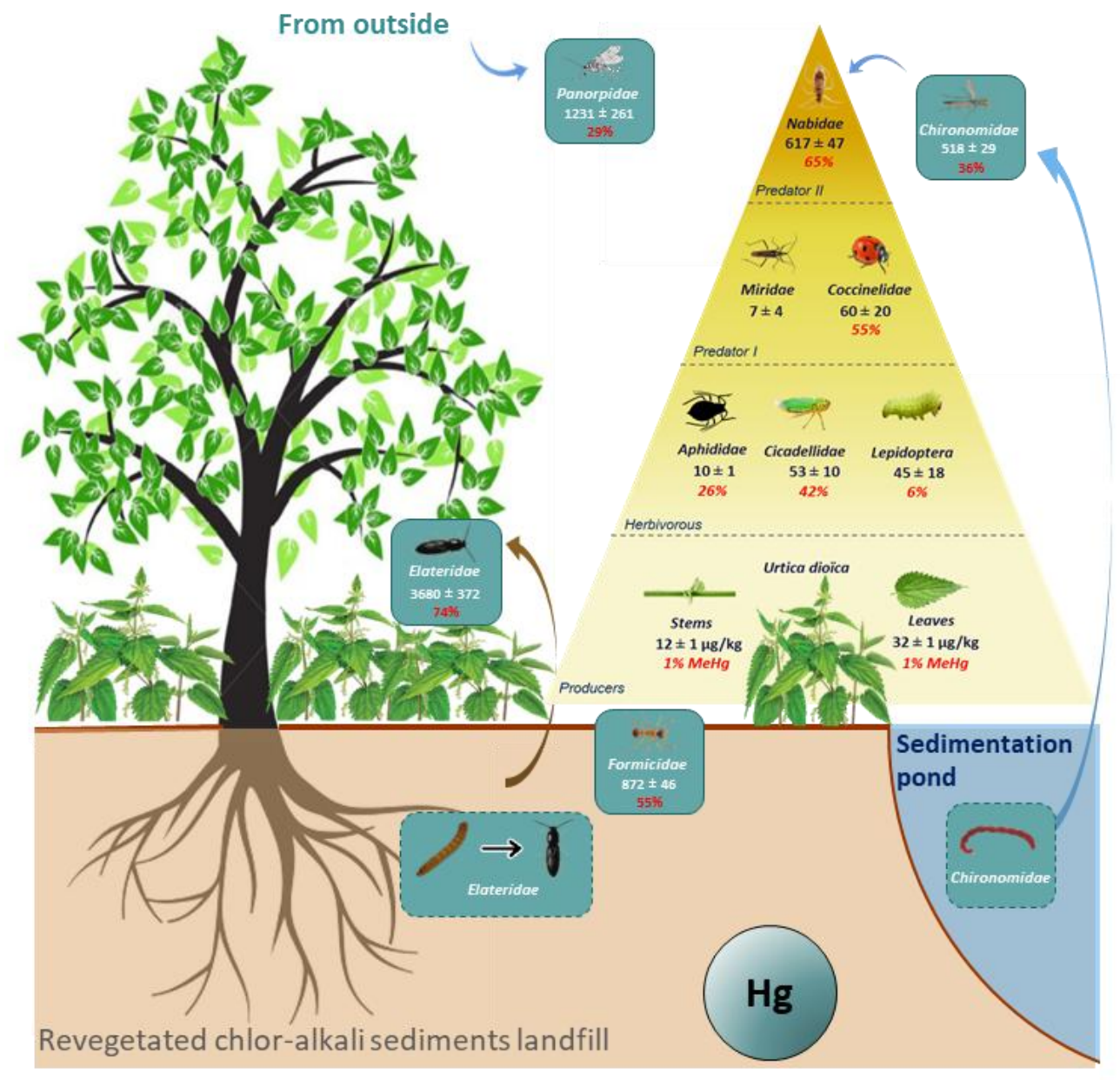

473 Figure 4: THg concentrations in the nettle-related food web (yellow pyramid) and the 474 implication of nettle-unrelated taxa in the flow of $\mathrm{THg}$ (blue boxes). $\mathrm{THg}$ concentrations 475 ( $\mu \mathrm{g} / \mathrm{kg}$ dry wt.) are specified under each name of taxa (mean $\pm \mathrm{SE}$ ), as well as the percentage 476 of $\mathrm{THg}$ as $\mathrm{MeHg}$ in bold red.

Our findings suggest that insects (e.g., Elateridae and Chironomidae) that had direct contact with terrestrial or underwater sediments constitute the main entry source of $\mathrm{Hg}$ within 479 the terrestrial nettle-insect food web (Figure 4). These insects may constitute direct food for 480 higher trophic levels (birds, mammals) or food for generalist predator insects. These latter 481 (i.e., Nabidae) are likely to play a role in the export of significant amounts of $\mathrm{Hg}$ at higher 482 trophic levels and become another major vector in the transfer of $\mathrm{Hg}$, as recently 483 demonstrated in temperate forest environment ${ }^{54}$. Other insect features of interest, such as 
dispersal capacity, vulnerability to predation, and nutritional value, would, however, need to

485 be considered to fully assess the role of insects within $\mathrm{Hg}$ dissemination in $\mathrm{Hg}$-contaminated 486 areas.

487

488

489

490

491

492

493

494

495

496

497

498

499

500

501

502

503

504

505

506

507

\section{ASSOCIATED CONTENT}

\section{Supporting information.}

Figure S1. Results from preliminary tests consisting of evaluating the influence of insect preservation methods on the THg concentrations measured in Nabis sp. (A) and Myrmica rubra (B) preserved in ethanol or directly ice-dried after collection.

Table S1. Ecological characteristics of each targeted taxa, including their link with nettle, habitat, trophic guild in the nettle-based food web, feeding guild and dietary range according to the literature

Table S2. Details of the MeHg analyses

\section{AUTHOR INFORMATION}

Corresponding Author

E-mail contact: michel.chalot@univ-fcomte.fr

Notes

The authors declare no competing financial interest.

\section{ACKNOWLEDGMENTS}

The authors gratefully acknowledge the funding provided by ADEME, France, under grant No. 1772C0018, PHYTOFIBER Project, and the Fondation de France and ADEME for their financial support to LY under a $\mathrm{PhD}$ grant. 


\section{REFERENCES}

(1) Rhee, S.-W. Control of mercury emissions: policies, technologies, and future trends https://www.dovepress.com/control-of-mercury-emissions-policies-technologies-and-futuretrends-peer-reviewed-fulltext-article-EECT (accessed Apr 8, 2019). https://doi.org/10.2147/EECT.S73403.

(2) Assad, M.; Parelle, J.; Cazaux, D.; Gimbert, F.; Chalot, M.; Tatin-Froux, F. Mercury uptake into poplar leaves. Chemosphere 2016, 146, 1-7. https://doi.org/10.1016/j.chemosphere.2015.11.103.

(3) Stamenkovic, J.; Gustin, M. S. Nonstomatal versus stomatal uptake of atmospheric mercury. Environ. Sci. Technol. 2009, 43 (5), 1367-1372. https://doi.org/10.1021/es801583a.

(4) Cronk, Q.; Hidalgo, O.; Pellicer, J.; Percy, D.; Leitch, I. Salix transect of Europe: variation in ploidy and genome size in willow-associated common nettle, Urtica dioica L. sens. lat., from Greece to arctic Norway. Biodivers. Data J. 2016, 4, e10003. https://doi.org/10.3897/BDJ.4.e10003.

(5) Davis, B. N. K. The European distribution of insects on stinging nettles, Urtica dioica L.: a field survey. Bolletino Zool. 1989, 56 (4), 321-326. https://doi.org/10.1080/11250008909355658.

(6) Alhmedi, A.; Haubruge, E.; Bodson, B.; Francis, F. Aphidophagous guilds on nettle (Urtica dioica) strips close to fields of green pea, rape and wheat. Insect Sci. 2007, 14 (5), 419-424. https://doi.org/10.1111/j.1744-7917.2007.00169.x.

(7) Alhmedi, A.; Haubruge, E.; D'Hoedt, S.; Francis, F. Quantitative food webs of herbivore and related beneficial community in non-crop and crop habitats. Biol. Control 2011, 58 (2), 103112. https://doi.org/10.1016/j.biocontrol.2011.04.005.

(8) James, D. G.; Lauby, G.; Seymour, L.; Buckley, K. Beneficial insects associated with stinging nettle, Urtica dioica Linnaeus, in Central Washington state. Pan-Pac. Entomol. 2015, 91 (1), 82-90. 
(9) Kidd, K.; Clayden, M.; Jardine, T. Bioaccumulation and biomagnification of mercury through food webs. In Environmental Chemistry and Toxicology of Mercury; John Wiley \& Sons, Ltd, 2011; pp 453-499. https://doi.org/10.1002/9781118146644.ch14.

(10) Rahman, Z.; Singh, V. P. The relative impact of toxic heavy metals (THMs) (arsenic (As), cadmium $(\mathrm{Cd})$, chromium $(\mathrm{Cr})(\mathrm{VI})$, mercury $(\mathrm{Hg})$, and lead $(\mathrm{Pb}))$ on the total environment: an overview. Environ. Monit. Assess. 2019, 191 (7), 419. https://doi.org/10.1007/s10661-019-7528-7.

(11) Nabi, S. Toxic effects of mercury; Springer India, 2014.

(12) Evers, D. The effects of methylmercury on wildlife: a comprehensive review and approach for interpretation. In Encyclopedia of the Anthropocene; Elsevier, 2018; pp 181-194. https://doi.org/10.1016/B978-0-12-809665-9.09985-7.

(13) Mahbub, K. R.; Krishnan, K.; Naidu, R.; Andrews, S.; Megharaj, M. Mercury toxicity to terrestrial biota. Ecol. Indic. 2017, 74, 451-462. https://doi.org/10.1016/j.ecolind.2016.12.004.

(14) Abeysinghe, K. S.; Qiu, G.; Goodale, E.; Anderson, C. W. N.; Bishop, K.; Evers, D. C.; Goodale, M. W.; Hintelmann, H.; Liu, S.; Mammides, C.; Quan, R. C; Wang, J.; Wu, P.; Xu, X. H.; Yang, X. D.; Feng, X. Mercury flow through an asian rice-based food web. Environ. Pollut. 2017, 229, 219228. https://doi.org/10.1016/j.envpol.2017.05.067.

(15) Rimmer, C. C.; Miller, E. K.; McFarland, K. P.; Taylor, R. J.; Faccio, S. D. Mercury bioaccumulation and trophic transfer in the terrestrial food web of a montane forest. Ecotoxicology 2010, 19 (4), 697-709. https://doi.org/10.1007/s10646-009-0443-x.

(16) Ullrich, S. M.; llyushchenko, M. A.; Tanton, T. W.; Uskov, G. A. Mercury contamination in the vicinity of a derelict chlor-alkali plant. Sci. Total Environ. 2007, 381 (1-3), 290-306. https://doi.org/10.1016/j.scitotenv.2007.02.020.

(17) Zhilong, M.; Qiang, W.; Zhongsheng, Z.; Xuehong, Z. Mercury distribution along the food chain of a wetland ecosystem at Sanjiang Plain, Northeast China. Bull. Environ. Contam. Toxicol. 2017, 98 (2), 162-166. https://doi.org/10.1007/s00128-016-2005-2. 
(18) Zhang, Z.; Song, X.; Wang, Q.; Lu, X. Mercury bioaccumulation and prediction in terrestrial insects from soil in Huludao City, Northeast China. Bull. Environ. Contam. Toxicol. 2012, 89 (1), 107-112. https://doi.org/10.1007/s00128-012-0649-0.

(19) Zhang, Z.-S.; Lu, X.-G.; Wang, Q.-C.; Zheng, D.-M. Mercury, Cadmium and lead biogeochemistry in the soil-plant-insect system in Huludao City. Bull. Environ. Contam. Toxicol. 2009, 83 (2), 255-259. https://doi.org/10.1007/s00128-009-9688-6.

(20) Zheng, D.; Liu, X.; Jin, D.; Li, H.; Li, X. Mercury bioaccumulation in arthropods from typical community habitats in a zinc-smelting area. Environ. Geochem. Health 2018, 40 (4), 13291337. https://doi.org/10.1007/s10653-017-0059-7.

(21) Zheng, D.-M.; Wang, Q.-C.; Zhang, Z.-S.; Zheng, N.; Zhang, X.-W. Bioaccumulation of total and methyl mercury by arthropods. Bull. Environ. Contam. Toxicol. 2008, 81 (1), 95-100. https://doi.org/10.1007/s00128-008-9393-x.

(22) Martin-Creuzburg, D.; Kowarik, C.; Straile, D. Cross-ecosystem fluxes: export of polyunsaturated fatty acids from aquatic to terrestrial ecosystems via emerging insects. Sci. Total Environ. 2017, 577, 174-182. https://doi.org/10.1016/j.scitotenv.2016.10.156.

(23) Blais, J. M.; Macdonald, R. W.; Mackay, D.; Webster, E.; Harvey, C.; Smol, J. P. Biologically mediated transport of contaminants to aquatic systems. Environ. Sci. Technol. 2007, 41 (4), 1075-1084. https://doi.org/10.1021/es061314a.

(24) Cristol, D. A.; Brasso, R. L.; Condon, A. M.; Fovargue, R. E.; Friedman, S. L.; Hallinger, K. K.; Monroe, A. P.; White, A. E. The movement of aquatic mercury through terrestrial food webs. Science 2008, 320 (5874), 335-335. https://doi.org/10.1126/science.1154082.

(25) Clayden, M. G.; Kidd, K. A.; Chételat, J.; Hall, B. D.; Garcia, E. Environmental, geographic and trophic influences on methylmercury concentrations in macroinvertebrates from lakes and wetlands across Canada. Ecotoxicology 2014, 23 (2), 273-284. https://doi.org/10.1007/s10646-013-1171-9. 
(26) Buckland-Nicks, A.; Hillier, K. N.; Avery, T. S.; O’Driscoll, N. J. Mercury bioaccumulation in dragonflies (Odonata: Anisoptera): examination of life stages and body regions. Environ. Toxicol. Chem. 2014, 33 (9), 2047-2054. https://doi.org/10.1002/etc.2653.

(27) Baxter, C. V.; Fausch, K. D.; Saunders, W. C. Tangled webs: reciprocal flows of invertebrate prey link streams and riparian zones. Freshw. Biol. 2005, 50 (2), 201-220. https://doi.org/10.1111/j.1365-2427.2004.01328.x.

(28) Akamatsu, F.; Toda, H. Aquatic subsidies transport anthropogenic nitrogen to riparian spiders. Environ. Pollut. Barking Essex 1987 2011, 159 (5), 1390-1397. https://doi.org/10.1016/j.envpol.2011.01.005.

(29) Alberts, J. M.; Sullivan, S. M. P. Factors influencing aquatic-to-terrestrial contaminant transport to terrestrial arthropod consumers in a multiuse river system. Environ. Pollut. 2016, 213, 5362. https://doi.org/10.1016/j.envpol.2016.02.003.

(30) Chaves-Ulloa, R.; Taylor, B. W.; Broadley, H. J.; Cottingham, K. L.; Baer, N. A.; Weathers, K. C.; Ewing, H. A.; Chen, C. Y. Dissolved organic carbon modulates mercury concentrations in insect subsidies from streams to terrestrial consumers. Ecol. Appl. 2016, 26 (6), 1771-1784. https://doi.org/10.1890/15-0025.1.

(31) Ortiz, C.; Weiss-Penzias, P. S.; Fork, S.; Flegal, A. R. Total and monomethyl mercury in terrestrial arthropods from the central California coast. Bull. Environ. Contam. Toxicol. 2015, 94 (4), 425430. https://doi.org/10.1007/s00128-014-1448-6.

(32) Parkman, H.; Meili, M. Mercury in macroinvertebrates from Swedish forest lakes: influence of lake type, habitat, life cycle, and food quality. Can. J. Fish. Aquat. Sci. 1993, 50 (3), 521-534. https://doi.org/10.1139/f93-061.

(33) Zappelini, C.; Karimi, B.; Foulon, J.; Lacercat-Didier, L.; Maillard, F.; Valot, B.; Blaudez, D.; Cazaux, D.; Gilbert, Yergeau, D; Greer, C., Chalot, M. Diversity and complexity of microbial communities from a chlor-alkali tailings dump. Soil Biol. Biochem. 2015, 90, 101-110. https://doi.org/10.1016/j.soilbio.2015.08.008. 
(34) Durand, A.; Maillard, F.; Foulon, J.; Gweon, H. S.; Valot, B.; Chalot, M. Environmental metabarcoding reveals contrasting belowground and aboveground fungal communities from poplar at a Hg phytomanagement site. Microb. Ecol. 2017. https://doi.org/10.1007/s00248017-0984-0.

(35) Giustina, W. della; Bonfils, J.; Le Quesne, W. J. Homoptères Cicadellidae; Faune de France; Institut national de la recherche agronomique: Paris, 1989.

(36) Péricart, J. Hémiptères Nabidae d'Europe Occidentale et Du Maghreb; Faune de France; Fédération française des sociétés de sciences naturelles: Paris, 1987.

(37) Maillard, F.; Girardclos, O.; Assad, M.; Zappelini, C.; Pérez Mena, J. M.; Yung, L.; Guyeux, C.; Chrétien, S.; Bigham, G.; Cosio, C.; Chalot, M. Dendrochemical assessment of mercury releases from a pond and dredged-sediment landfill impacted by a chlor-alkali plant. Environ. Res. 2016, 148, 122-126. https://doi.org/10.1016/j.envres.2016.03.034.

(38) Liu, B.; Yan, H.; Wang, C.; Li, Q.; Guédron, S.; Spangenberg, J. E.; Feng, X.; Dominik, J. Insights into low fish mercury bioaccumulation in a mercury-contaminated reservoir, Guizhou, China. Environ. Pollut. 2012, 160, 109-117. https://doi.org/10.1016/j.envpol.2011.09.023.

(39) Bloom, N. Determination of picogram levels of methylmercury by aqueous phase ethylation, followed by cryogenic gas chromatography with cold vapour atomic fluorescence detection. Can. J. Fish. Aquat. Sci. 1989, 46 (7), 1131-1140. https://doi.org/10.1139/f89-147.

(40) Borgå, K.; Kidd, K. A.; Muir, D. C.; Berglund, O.; Conder, J. M.; Gobas, F. A.; Kucklick, J.; Malm, O.; Powell, D. E. Trophic magnification factors: considerations of ecology, ecosystems, and study design. Integr. Environ. Assess. Manag. 2012, 8 (1), 64-84. https://doi.org/10.1002/ieam.244.

(41) Rodenhouse, N. L.; Lowe, W. H.; Gebauer, R. L. E.; McFarland, K. P.; Bank, M. S. Mercury bioaccumulation in temperate forest food webs associated with headwater streams. Sci. Total Environ. 2019, 665, 1125-1134. https://doi.org/10.1016/j.scitotenv.2019.02.151. 
(42) Sasmaz, M.; Akgül, B.; Yıldırım, D.; Sasmaz, A. Mercury uptake and phytotoxicity in terrestrial plants grown naturally in the Gumuskoy (Kutahya) mining area, Turkey. Int. J. Phytoremediation 2016, 18 (1), 69-76. https://doi.org/10.1080/15226514.2015.1058334.

(43) He, Z. L.; Yang, X. E.; Stoffella, P. J. Trace elements in agroecosystems and impacts on the environment. J. Trace Elem. Med. Biol. 2005, 19 (2), 125-140. https://doi.org/10.1016/j.jtemb.2005.02.010.

(44) Kabata-Pendias, A. Trace elements in soils and plants, 4th ed.; CRC Press: Boca Raton, 2011.

(45) Kabata-Pendias, A.; Mukherjee, A. B. Trace elements from soil to human: With 209 Tables; Springer: Berlin, 2007.

(46) Meng, B.; Feng, X.; Qiu, G.; Wang, D.; Liang, P.; Li, P.; Shang, L. Inorganic mercury accumulation in rice (Oryza sativa L.). Environ. Toxicol. Chem. 2012, 31 (9), 2093-2098. https://doi.org/10.1002/etc.1913.

(47) Macnicol, R. D.; Beckett, P. H. T. Critical tissue concentrations of potentially toxic elements. Plant Soil 1985, 85 (1), 107-129. https://doi.org/10.1007/BF02197805.

(48) Stolpe Nordin, E. Life cycle of Agriotes wireworms and their effect in maize cultivation. 2017.

(49) Byers, G. W.; Thornhill, R. Biology of the Mecoptera. Annu. Rev. Entomol. 1983, 28 (1), 203-228. https://doi.org/10.1146/annurev.en.28.010183.001223.

(50) Pinder, L. C. V. Biology of freshwater Chironomidae. Annu. Rev. Entomol. 1986, 31 (1), 1-23.

(51) Kraus, J. M.; Walters, D. M.; Wesner, J. S.; Stricker, C. A.; Schmidt, T. S.; Zuellig, R. E. Metamorphosis alters contaminants and chemical tracers in insects: implications for food webs. Environ. Sci. Technol. 2014, 48 (18), 10957-10965. https://doi.org/10.1021/es502970b.

(52) Beauvais-Flück, R.; Gimbert, F.; Méhault, O.; Cosio, C. Trophic fate of inorganic and methylmercury in a macrophyte-chironomid food chain. J. Hazard. Mater. 2017, 338, 140-147. https://doi.org/10.1016/j.jhazmat.2017.05.028. 
656 (53) Beckert, W. F.; Moghissi, A. A.; Au, F. H. F.; Bretthauer, E. W.; Mcfarlane, J. C. Formation of 657 methylmercury in a terrestrial environment. Nature 1974, 249 (5458), 674-675. https://doi.org/10.1038/249674a0.

659 (54) Tsz-Ki Tsui, M.; Liu, S.; Brasso, R. L.; Blum, J. D.; Kwon, S. Y.; Ulus, Y.; Nollet, Y. H.; Balogh, S. J.; Eggert, S. L.; Finlay, J. C. Controls of methylmercury bioaccumulation in forest floor food webs. Environ. Sci. Technol. 2019, 53 (5), 2434-2440. https://doi.org/10.1021/acs.est.8b06053.

(55) Swanson, D. A Synopsis of the damsel bugs (Heteroptera: Nabidae) of Michigan. Gt. Lakes Entomol. 2012, 45, 40-55.

(56) Gann, G. L.; Powell, C. H.; Chumchal, M. M.; Drenner, R. W. Hg-contaminated terrestrial spiders pose a potential risk to songbirds at Caddo lake (Texas/Louisiana, USA). Environ. Toxicol. Chem. 2015, 34 (2), 303-306. https://doi.org/10.1002/etc.2796. 